\title{
Narratives and interpretations of the political economy of Zimbabwe's development aid trajectory, 1980-2013
}

\begin{tabular}{|c|c|}
\hline \multicolumn{2}{|c|}{$\begin{array}{l}\text { Authors: } \\
\text { Blessing Magocha }{ }^{1} \text { ( } \\
\text { Edmore Mutekwe }^{2} \text { (D) }\end{array}$} \\
\hline \multicolumn{2}{|c|}{$\begin{array}{l}\text { Affiliations: } \\
\text { 'Department of Development } \\
\text { Studies, Faculty of } \\
\text { Humanities, North-West } \\
\text { University, Mafikeng, } \\
\text { South Africa }\end{array}$} \\
\hline \multicolumn{2}{|c|}{$\begin{array}{l}\text { 2School of Professional } \\
\text { Studies in Education, Faculty } \\
\text { of Education, North-West } \\
\text { University, Mafikeng, } \\
\text { South Africa }\end{array}$} \\
\hline \multicolumn{2}{|c|}{$\begin{array}{l}\text { Corresponding author: } \\
\text { Edmore Mutekwe, } \\
\text { Edmore.mutekwe@nwu.ac.za }\end{array}$} \\
\hline \multicolumn{2}{|c|}{$\begin{array}{l}\text { Dates: } \\
\text { Received: } 11 \text { June } 2020 \\
\text { Accepted: } 12 \text { Nov. } 2020 \\
\text { Published: } 04 \text { Feb. } 2021\end{array}$} \\
\hline \multicolumn{2}{|c|}{$\begin{array}{l}\text { How to cite this article: } \\
\text { Magocha B, Mutekwe E. } \\
\text { Narratives and } \\
\text { interpretations of the } \\
\text { political economy of } \\
\text { Zimbabwe's development aid } \\
\text { trajectory, 1980-2013. } \\
\text { J transdiscipl res S Afr. } \\
\text { 2021;17(1), a896. https://doi. } \\
\text { org/10.4102/td.v17i1.896 }\end{array}$} \\
\hline \multicolumn{2}{|c|}{$\begin{array}{l}\text { Copyright: } \\
\text { (C) 2021. The Authors. } \\
\text { Licensee: AOSIS. This v } \\
\text { is licensed under the } \\
\text { Creative Commons } \\
\text { Attribution License. }\end{array}$} \\
\hline \multicolumn{2}{|l|}{ Read online: } \\
\hline 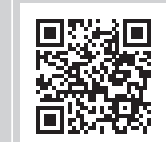 & $\begin{array}{l}\text { Scan this QR } \\
\text { code with your } \\
\text { smart phone or } \\
\text { mobile device } \\
\text { to read online. }\end{array}$ \\
\hline
\end{tabular}

\begin{abstract}
The purpose of this conceptual study is to analyse the political economy of Zimbabwe's development aid trajectory from 1980 to 2013. The discussion unfolds around four historical epochs: colonial legacy, land and independence from 1980 to 1990; the Economic Structural Adjustment Programme (ESAP) 1991-2000; The Multi-Party Democracy period 2001-2008 and the Government of National Unity (GNU) 2008-2013. In doing so, the discourse offers a critical discussion of the factors that have characterised the flow of aid to Zimbabwe. It also explores the historical, socio-economic and political events that shaped development policies and outcomes in Zimbabwe from 1980 to 2013. The study also explores the scale, interaction and impact of aid flow to Zimbabwe. This study is purely qualitative and uses documentary reviews as part of the literature review to extrapolate the relevant data. In this study, we argue that the flow of aid is politically motivated. The study recommends that the Zimbabwean government should come up with a robust aid coordination policy in order to fully guide the inflow of donor aid.
\end{abstract}

Keywords: aid; development; political economy; aid policy; Zimbabwe.

\section{Introduction}

The conceptual study seeks to analyse the development aid trajectory in Zimbabwe from 1980 to 2013 within the context of the political economy approach. The study thus analyses the status of development aid mainly from the point of view of factors that have characterised the flow of aid in Zimbabwe in terms of both explicit and implicit policies, legal frameworks, structures and decisions taken ${ }^{1}$ by both the Zimbabwean Government and donors. The study also seeks to analyse the scale, impact and interaction of aid flows to Zimbabwe. It also seeks to establish events that shaped development aid policies and outcomes, with a special interest in policy commission and/or omission by political institutions., ${ }^{2,3}$ It unpacks the various historical, socio-economic and political events which we considered very critical in shaping Zimbabwe's development aid trajectory: land, colonial legacy and independence; the Economic Structural Adjustment Programme (ESAP) of the years 1991-2000; the multi-party democracy period, 2001-2008 and lastly, the government of national unity (GNU) of 2009-2013. These epochs are very critical because of the major socio-economic and political events that occurred which had a bearing on the in- and out-flow of development aid to Zimbabwe. Each of these events is explored to develop an understanding of the development aid trajectory from the early independence years, 1980-2013 in Zimbabwe. The issue of how aid has affected the socio-economic and political well-being of the people of Zimbabwe is also brought under the spotlight.

\section{Background to the study}

Aid is very significant and has remained a key source of external finance in least developed states, ahead of diaspora remittances. ${ }^{4}$ The developing countries, most of them found in Africa, heavily depend on aid because they suffer from significant resource constraints and it is very difficult for them to access other external resources such as foreign direct investment. ${ }^{5}$ It is for this reason that aid remains a vital source for development. Zimbabwe is amongst the recipients of foreign aid from many countries and international monetary agencies. In fact, Chung ${ }^{6}$ asserts that Zimbabwe was a favoured destination for aid until the political turmoil of the early 2000s in the country, which led to donors withholding aid culminating in less aid being disbursed to Harare. As one of the darling of the developed world's donors, who were prepared to pour in about USD300 million into the country each year, ${ }^{6}$ Zimbabwe recorded many of the celebrated cases of health and education delivery in the first decade of her independence. ${ }^{7,8}$ 
However, it is important to note that during the 1990s relations between the government and donors became sour because of alleged human and property rights violations, coupled with mistrust and the political turmoil of the early 2000s. ${ }^{7}$ Nyazema $^{8}$ and Bonarjee ${ }^{9}$ note that despite the tenuous donor-government relations, aid remained a vital component to socio-economic development in Zimbabwe. Several aid-funded programmes and projects to improve maternal and child health, access to and quality of water supply and sanitation were implemented. ${ }^{10,11,12,13}$ For instance, donor receipt of aid to health increased from 32\% in 1998-2000 to $49 \%$ in 2004, with the ministry of health confirming that donors were a significant source of funding for health. ${ }^{3}$

In spite of the much publicised human and property rights violations in 2000, donor organisations such as Danish International Development Agency (DANIDA), Norwegian Agency for Development Cooperation (NORAD) and the European Union (EU) disbursed funds to Zimbabwe to sustain the health budget through the Health Services Fund. ${ }^{8}$ The health sector in Zimbabwe relies heavily on donor aid as most drugs come as donations and are thus procured externally. ${ }^{14}$ The Health Transition Fund pays for the purchase of $98 \%$ of the drugs, whilst the remaining $2 \%$ is paid for by the AIDS levy managed by the National AIDS Council (NAC). ${ }^{13}$ Donor-driven projects have aided vulnerable groups in Zimbabwe, especially orphans who were affected by the hyper-endemic HIV. ${ }^{11,15}$ Further to this, Zimbabwe has benefited immensely from technical and capacity-building projects funded by different donors, ${ }^{10}$ and this has seen many projects undertaken in areas such as agriculture, power stations and railway services. ${ }^{16}$ Often, the government of Zimbabwe (GoZ) has had no capacity to run complex sets of programmes, but the donors on many occasions have turned providers..$^{15}$ For instance, donorfunding has improved availability of medicines and medical staff in healthcare facilities across Zimbabwe. ${ }^{13}$

The GoZ puts structures in place to ensure that aid is effectively and efficiently managed. ${ }^{17}$ The main structures put in order of their occurrences are the Zimbabwe Conference on Reconstruction and Development (ZIMCORD), which was put in place to provide a coordinated response to rebuilding processes and aid. ${ }^{18}$ The NAC and the National AIDS Trust Fund, popularly known as the AIDS Levy are responsible for the coordination and implementation of programmes and measures to combat HIV and AIDS. Whilst the AIDS Levy is there to provide financial support to key HIV and AIDS interventions in Zimbabwe as well as complementing the external funding of HIV and AIDS activities in Zimbabwe, ${ }^{19}$ there is the Aid Coordination Policy (ACP), which was enacted in May 2009 to provide a framework for enhanced aid effectiveness and accountability. ${ }^{14}$ It was designed in line with the principles of the Paris Declaration on Aid Effectiveness (PDAE) and the Accra Agenda for Action. ${ }^{14}$ It was also created to minimise duplication and aligning aid with national development plans and priorities by building institutional frameworks to improve the effectiveness of aid in Zimbabwe. ${ }^{14,20}$ The other equally important objective was to re-orient aid from humanitarian to development assistance. $^{20}$ The Government Development Forum (GDF) was also created as a platform for promoting dialogue between governments and donor partners. ${ }^{14,20}$ However, the ACP suffered major setbacks such as lack of capacity, fights for control by multi-parties and line ministries during the GNU as well as reluctance by some donor countries to engage directly with the government and hence, it was rendered ineffective. ${ }^{15}$ The GoZ has continued to be vulnerable with no balance of payment support from major multilateral and bilateral institutions or donors as a result of huge debt arrears of over $\$ 7$ billion and an almost $\$ 2 \mathrm{~b}$ domestic debt. ${ }^{21}$ Other sectors have been severely affected too, especially the health sector that has been in decline, resulting in a decrease in coverage of most basic services and a rising maternal and child mortality rate. ${ }^{3}$

\section{Aim and objectives of the study}

The aim of this study was to explore the political economy of Zimbabwe's development aid trajectory for the period 1980-2013. Pursuant to this broad aim, the following objectives were set:

- To examine the factors that have characterised the flow of aid to Zimbabwe in the period 1980-2013.

- To identify the historical, socio-economic and political events that characterised development aid policies and outcomes in Zimbabwe in the period 1980-2013.

- To establish the scale and impact of aid flow to Zimbabwe between 1980 and 2013.

- To determine how the strings attached to the donor aid flow to Zimbabwe created tensions between the Zimbabwe government and the donor community when the former engaged in human and property rights violations.

\section{The research problem}

In spite of all the efforts in terms of the ZIMCORD, the draft $\mathrm{ACP}$ and the GDF put in place by the GoZ, there is a growing convergence of opinion by academics and development experts that aid has grossly failed to achieve its intended outcomes. $8,11,15,22,23,24$ The GoZ has received aid from various donors to address various humanitarian and development issues. However, there is very little empirical evidence showing the effectiveness of the aid. In addition, donorfunding posed a challenge to government institutions in coordinating multiple stakeholders and balancing various external interest groups to achieve a common goal. ${ }^{15}$ For example, donor participation in the health sector in Zimbabwe has been composed of different individual organisations, each with differing objectives and operational methods, and in general are known not to cooperate with each other in a way that would allow coherent policymaking. ${ }^{8}$ The weak aid coordination mechanisms give rise to the continued reluctance of some donors to engage directly with government. ${ }^{15}$ Many bilateral donors have opted to channel their aid through UN and non-state organisations, rather 
than through the GoZ for fear of misappropriation, corruption and politicisation of funds by the government. ${ }^{11}$

\section{Significance of the study}

The studies that have been done in Zimbabwe on aid include; a study by Chikowore, ${ }^{24}$ who did an examination of macroeconomic indicators of Zimbabwe in relation to aid, including its debt situation and implementation of the Millennium Development Goals (MDGs) in order to analyse the effectiveness of development aid, Muchadenyika ${ }^{25}$ focused on assessing aid effectiveness of the Zimbabwe multi-donor trust fund and lastly, Moyo and $\mathrm{Mafuso}^{26}$ also on the effectiveness of foreign aid in Zimbabwe between 1965 and 2008, concluding that foreign aid immensely contributed to the Zimbabwean economy. The present study is unique because it focuses on the effects of politics on the flow of aid and how the flow affects the political and socio-economic environment of Zimbabwe. Consequently, the findings of this study are envisaged to practically contribute to a better understanding of the operation of development aid in Zimbabwe. It is expected to enable the Government to be able to effectively coordinate donor funding. It also hoped that the study would help contribute theoretically to academic literature on aid management in Zimbabwe so as to empower policymakers and donors, through the recommendations made in appreciation of the challenges involved in the implementation of development aid.

\section{Theoretical framework}

The study adopted the modernisation theory as the framework underpinning the discussion. According to Giddens ${ }^{27}$ the modernisation theory is a set of concepts that seek to explain how development is considered a product of following trends the developed nations of the West followed. According to this perspective, developments in the West and America, hereinafter called the centre, should be used as the yardstick for ensuring that nations in the south of the global village, hereinafter called peripheral nations, are uplifted. ${ }^{28,29}$ Gunder-Frank ${ }^{30}$ further asserts that it is upon this notion that the concepts of developed and developing nations were coined. The implications for this are that donor organisations such as the Bretton Woods institutions (International Monetary Fund [IMF] and World Bank), need to keep pouring donations to the peripheral nations for them (peripheral nations) to develop to the levels attained by the developed global North or Centre of the global village. ${ }^{31}$ Such a mind-set has engendered a dependency syndrome in many peripheral nations, especially in Africa, and Zimbabwe is one such country. ${ }^{26,29}$ The ensuing discussion thus unpacks the political economy of development aid in Zimbabwe by focusing on the colonial legacy of aid in Zimbabwe from 1980 to 1990.

\section{Colonial legacy and aid in Zimbabwe 1980-1990}

The flow of aid during this period was largely influenced by the need to reconstruct a nation that had been politically, socially and economically affected by the war of liberation which ended in $1980 .{ }^{32}$ Amongst other issues that affected the inflow of aid to Zimbabwe were the bipolar nature of global politics nuanced in the cold war discourses on the one hand and, bilateral and colonial ties with hegemonic Britain on the other. ${ }^{33}$ Land was the central theme of contention when the black African majority of Zimbabwe waged the war of liberation against the white minority that had the privilege of owning a major portion of the land through a system of patronage that perpetuated racial segregation enshrined in Acts such as the 1930 Land Apportionment Act, ${ }^{9}$ the Maize Control Act of 1931, the Cattle Levy Act of 1931 and the Native Registration Act of 1936. ${ }^{34,35}$ The colonial rule underdeveloped and forced black people to occupy overcrowded and infertile lands located mainly in agro-ecological regions IV and $\mathrm{V}$ which made agriculturally based livelihood system unviable. ${ }^{36}$ The agro-ecological zones were divided according to the amount of rainfall they received with those that received high rainfall mainly found in the northern provinces and low and uncertain rainfall in the southern provinces. ${ }^{34}$

Whites occupied the highest rainfall areas and fertile lands, commonly found in regions I, II and III. African peasant families were forced into the labour market, usually at lower rates of wages. ${ }^{9,18,32}$ In fact, the black Africans were relegated to less productive areas called the African Purchase Areas and Tribal Trust Land. ${ }^{33}$ Because of the policy imbalances which guaranteed whites the accepted privilege to exploit the blacks, only 4000 large-scale white commercial farmers occupied 11.2 million hectares of land, whilst more than 1 million rural families occupied 16.3 million hectares of dry, less fertile and less productive lands, and 10000 small-scale farmers occupied 1.2 million hectares. ${ }^{36,37}$ To address the land issue, Zimbabwe pursued and received both bilateral and multilateral aid from various sources ${ }^{38}$ and it became a donor favourite. Donors were prepared to pour in about USD\$300m dollars into the country each year. ${ }^{6}$ Generous donors soon after independence included Swedish International Development Aid (SIDA), the Danish World University Services, the Humanist Institution for Cooperation with Developing Countries (HIVOS); Bread for the World, Swiss Christian Aid, Save the Children - United Kingdom (UK) and United States of America (USA), and the United Nations Children's Education Fund (UNICEF). ${ }^{6}$

As a way of addressing the land issue, over 62000 families were resettled between 1981 and 1987 on 2 million hectares of land that had been purchased by the government under the 'willing seller-willing buyer' system; partially funded by the Conservative British Government under Margaret Thatcher. ${ }^{9,39}$ This was in direct response to the bill of rights incorporated in the Lancaster House Agreement which committed the government to paying compensation for underutilised land owned by the white commercial farmers, if it is compulsorily acquired. ${ }^{32}$ In fact, at the 1979 Lancaster House Conference, the nationalists pledged to introduce major land redistribution. In return, developed nations, particularly Britain, promised substantial funding to ensure a willing-buyer, willing-seller basis for the new government's acquisition of land..$^{6,39,40}$ The Thatcher 
government provided a total of 44 million pounds for the resettlement projects. Unfortunately, the Blair Labour Government through Minister Clare Short refused to take the responsibility for funding land reform in Zimbabwe in 1997. ${ }^{39}$ The Labour Government alleged that there was corruption and patronage in the land resettlement processes. ${ }^{6,40,41}$ The British Government, which had granted $40 \mathrm{~m}$ British Pounds $(£ 40 \mathrm{~m})$ for land redistribution since independence stopped the grant alleging corruption. For example, 98 farms acquired by compulsory purchase grant were given to powerful party members. ${ }^{39}$ As a result, the amount of aid drastically reduced as shown in Figure 1.

\section{Reconstruction and development aid 1981-1984}

In order to have a coordinated response to the rebuilding process and attract the much-needed development aid, the government convened the ZIMCORD in March 1981. ${ }^{18,43}$ According to the ZIMCORD agenda, Zimbabwe needed aid to the tune of $\$ 1.2 \mathrm{~b}$ Zimbabwean dollars which was for public sector programme replenishment over a 4 year period, 1981-1984..$^{38,43}$ The estimated total financial requirements for the private and public sectors over the same period was estimated at $\$ 4 \mathrm{~b}$ Zimbabwe dollars. ${ }^{38}$ The reconstruction and development aid that was required from external sources was $\$ 2.3 \mathrm{~b}$ Zimbabwe dollars, broken down as follows: completion of refugee programme $\$ 36 \mathrm{~m}$; completion of reconstruction programme $\$ 98 \mathrm{~m}$; land settlement and rural agriculture development $\$ 786 \mathrm{~m}$; capital investment in training institutions $\$ 234 \mathrm{~m}$; technical assistance $\$ 100 \mathrm{~m} .{ }^{32}$
The conference presented Zimbabwe as a favoured destination of development aid. Huge amount of money in aid was pledged; in fact, almost $\$ 1.3 \mathrm{~b}$ was pledged, which rose to $\$ 1.8 \mathrm{~b}$ with post ZIMCORD pledges. ${ }^{38}$ In summary, pre-ZIMCORD commitments accounted for $\$ 365 \mathrm{~m}$ of the initial sum, 53\% came in soft loan form and $47 \%$ as grants. Some $94 \%$ came from developed nations; $\$ 177 \mathrm{~m}$ from the United Kingdom and $\$ 172.6 \mathrm{~m}$ from United States of America. ${ }^{38}$ Table 1 shows the details of development aid pledges made at the ZIMCORD Conference. The name of the donor is identified, including the source of development aid and the amount that was pledged.

Colonial ties are one of the particular influential criteria in aid decisions. ${ }^{6,44,45}$ According to the core-periphery model, development aid flows are usually unidirectional; from former colonial power(s) (hegemonic state or core) to former colonised state(s) (hinterland or periphery). As shown in Table 1, United Kingdom pledged more than any other donor except World Bank. In order to show its commitment, on 15 April, Lord Carrington announced that the British Government intended to commit over 3 years of aid totalling $75 \mathrm{~m}$ Pounds to Zimbabwe. ${ }^{33}$ This sum was going to be disbursed as follows: a 7-m Pound grant for urgent post-war reconstruction, 500000 Pounds for joint funding with voluntary agencies in Zimbabwe, and contribution to the UK share of expenditure resulting from the extension of the Lome Convention to Zimbabwe as well as the UK contribution to the special appeal by the United Nations High Commissioner for Refugees (UNHCR) in respect of Zimbabwe. In the process, Britain unveiled freebies in areas of education and

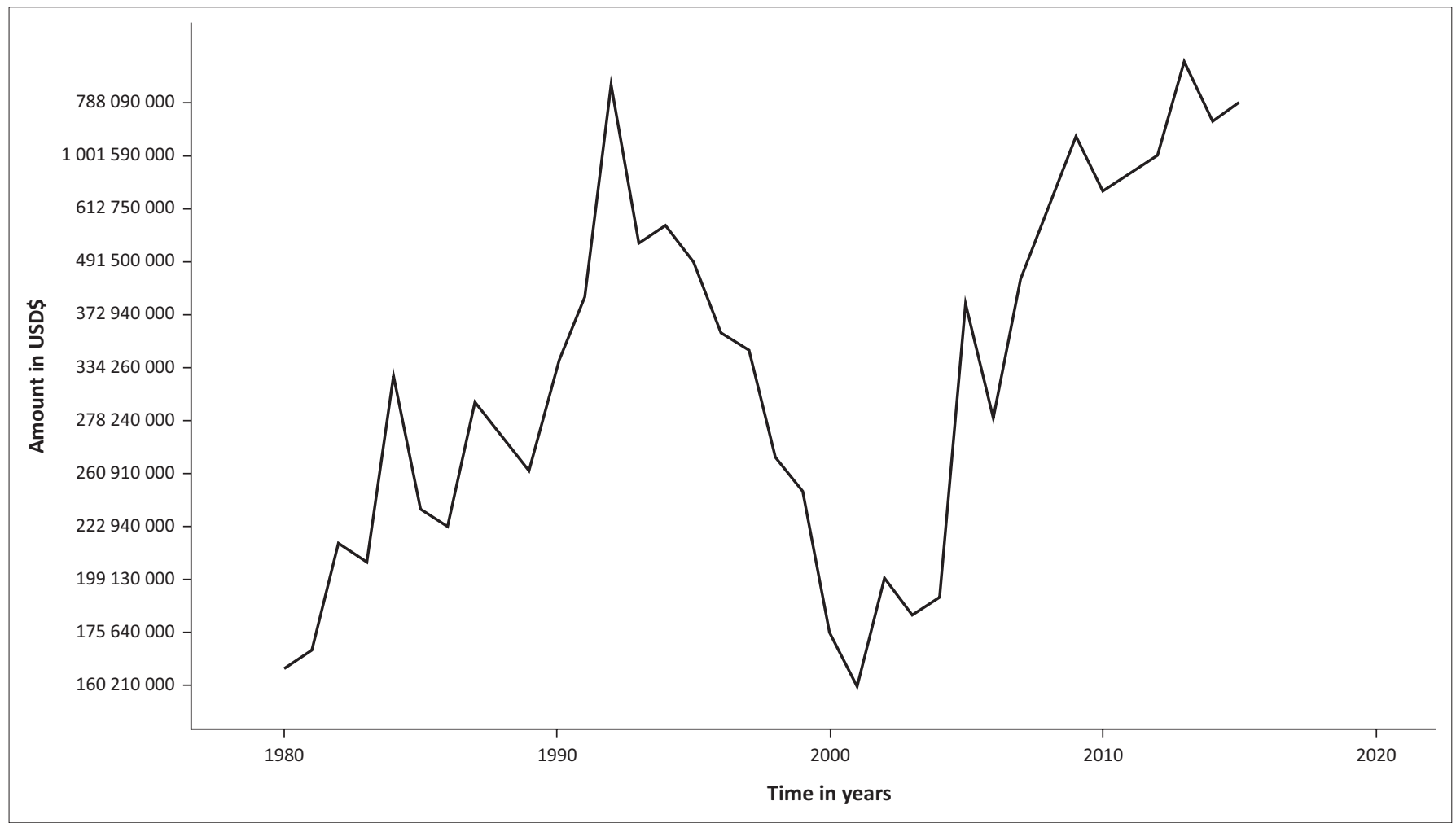

Source: Adapted from 'development aid at a glance', statistics by region-OECD, 2016. ${ }^{42}$

ODA, official development assistance.

FIGURE 1: Net official development assistance and official aid for Zimbabwe from 1980 to 2015. 
TABLE 1: Zimbabwe conference on reconstruction and development pledges 1981-1984 in Zimbabwean dollars.

\begin{tabular}{llll}
\hline Donor & $\begin{array}{l}\text { Pledge ZWD } \\
\text { (million) }\end{array}$ & Donor & $\begin{array}{l}\text { Pledge ZWD } \\
\text { (million) }\end{array}$ \\
\hline $\begin{array}{l}\text { African development } \\
\text { bank }\end{array}$ & 39.8 & Ireland & 0.045 \\
$\begin{array}{l}\text { Arab development bank } \\
\text { for economic } \\
\text { development in Africa }\end{array}$ & 31.3 & Luxembourg & 1.9 \\
$\begin{array}{l}\text { Australia } \\
\text { Belgium }\end{array}$ & 14.6 & Netherlands & 16.2 \\
\hline Canada & 8.0 & New Zealand & 0.174 \\
China & 33.3 & Nigeria & 12.4 \\
Denmark & 17.5 & Norway & 11.3 \\
\hline EEC & 12.5 & OPEC & 6.3 \\
Egypt & 120.0 & Saudi Arabia & 3.1 \\
\hline Finland & 1.3 & Sierra Leone & 0.056 \\
France & 5.2 & Sweden & 55.4 \\
\hline West Germany & 71.4 & Switzerland & 66.3 \\
\hline Ghana & 62.3 & UK & 177.0 \\
\hline Holy See & 0.63 & UN & 26.4 \\
\hline Italy & 12.5 & USA & 172.6 \\
\hline Japan & 23.1 & World Bank & 287.5 \\
\hline Jersey & 3.08 & Yugoslavia & 2.8 \\
\hline Kuwait & 0.075 & Commonwealth & 2.9 \\
\hline Soure: Adated & 32.5 & - & - \\
\hline
\end{tabular}

Source: Adapted from status report on external development assistance to Zimbabwe Ministry of Finance Economic Planning and Development 1986.

ZWD, Zimbabwean Dollar; EEC, European Economic Community; OPEC, Organization of the Petroleum Exporting Countries; UK, United Kingdom; UN, United Nations; USA, United States of America.

health to those who were earning less than Z\$150 a month. The reconstruction programme inspired rehabilitation of rural clinics, which were either closed or destroyed during the war. Zimbabwe had the opportunity to get aid in the form of grants and technical cooperation which was being provided together with grant money. It got capital aid which was provided as loans at $2 \%$ interest, with 25 years maturity and 7 years grace period on amortisation. ${ }^{33}$

War friends, China and Union of the Soviet Socialist Republics (USSR), governments and agencies which had acted in solidarity with liberation forces maintained their ties with the new government through aid commitments. Amongst them were SIDA, and USAID who contributed immensely to the reconstruction of the country through building of schools and training of teachers. As shown on Table 1, the largest multilateral donor at ZIMCORD was the World Bank. Between 1980 and 1989, the GoZ signed 15 loan agreements with the World Bank amounting to the USD541m in direct assistance and most of the loans attracted co-financing grants from bilateral donors. ${ }^{38}$

\section{The fall and break-up of the Union of the Soviet Socialist Republics}

The historical developments that took place in the 1990s, including the fall of the Soviet Union and of communism as a dependable global political and economic ideology shaped the future of development aid in Zimbabwe. When the USSR broke-up, the largesse towards Africa in general, and Zimbabwe in particular, ceased. ${ }^{6}$ The collapse of the Soviet Union made developed countries, especially the United States of America and the United Kingdom to lose interest in providing aid to Zimbabwe because of changes in perceptions
TABLE 2: The OECD flow of official development assistance to Zimbabwe from 2010 to 2012.

\begin{tabular}{lccc}
\hline Variable & $\mathbf{2 0 1 0}$ & $\mathbf{2 0 1 1}$ & $\mathbf{2 0 1 2}$ \\
\hline Receipts & & & \\
Net ODA (USD million) & 732 & 716 & 1001 \\
Bilateral share (gross ODA) & $71 \%$ & $75 \%$ & $67 \%$ \\
Net ODA/GNI & $10.4 \%$ & $7.8 \%$ & $9.8 \%$ \\
Net private flows (USD million) & 33 & 6 & 32 \\
For reference & & & \\
Population (million) & 13.1 & 13.4 & 13.7 \\
GNI per capita (Atlas USD) & 460 & 590 & 680 \\
\hline
\end{tabular}

Source: Adapted from OECD - Development Assistance Cooperation (DAC), World Bank, https://www.oecd.org/dac/stats.

ODA, Official Development Assistance; GNI, Gross National Input.

TABLE 3: Top 10 donors of gross official development assistance to Zimbabwe, (2011-2012 average).

\begin{tabular}{llc}
\hline Number & Donor & USD million \\
\hline 1 & United States & 177 \\
2 & United Kingdom & 149 \\
3 & Global Fund & 126 \\
4 & EU Institutions & 94 \\
5 & Germany & 58 \\
6 & Australia & 50 \\
7 & Sweden & 39 \\
8 & Denmark & 26 \\
9 & Norway & 25 \\
10 & Japan & 20 \\
\hline
\end{tabular}

Source: Adapted from OECD - DAC, World Bank, https://www.oecd.org/dac/stats. EU, European Union.

on the benefits of aid provisioning. Prior to the breakup of the Soviet Union, Zimbabwe had received substantial amount of aid, as a way of promoting the capitalist ideology and swaying Zimbabwe African National Union Patriotic Front (ZANU PF). From a radical heritage of Marxist ideology, which advocated a form of socialist rural economy with Yugoslavia, Romania, Bulgaria and China as contemporary models. ${ }^{32}$ According to Chung, ${ }^{6}$ one effect of the loss of donor funding in Zimbabwe was the weakening of the non-governmental organisation (NGO) sector which had enjoyed generous donor funding. This sector had largely depended on outside funding and was not able to adjust quickly to local sources of funding. Most of the NGOs provided services to the poorest sectors of society. ${ }^{6}$

\section{The economic structural adjustment programme in Zimbabwe 1991-2000}

The ESAP were funded by the Bretton Woods Institutions, the World Bank and IMF and they affected both the inflow and outflow of aid to Zimbabwe. ${ }^{36}$ Economic Structural Adjustment Programmes were formally introduced in Zimbabwe in October 1990, but started in earnest in March 1991 after a meeting with foreign aid agencies and the World Bank in Paris. ${ }^{46}$ The government, donor community and IMF/World Bank was of the belief that public expenditure reforms would lead to price stability and an improvement in the cost-effectiveness of the provision of social services. ${ }^{47}$ Riddell ${ }^{48}$ points out those recipients were encouraged to open their markets, privatise state assets, adopt a more export-oriented, less protective trade regime as a quid pro quo for receiving aid, and reduce direct government expenditures. As a result, the government received aid from World Bank, IMF and other 
donors, and as shown in Figure 1 aid inflow rose sharply during the inception years of ESAP. The aid was premised on the condition that the government would implement the structural reforms. The International Financial Institutions (IFIs) and the bilateral donor community also assumed that ESAP would promote good governance and democracy in the country, which were considered vital conditions for tackling corruption. ${ }^{49}$ The key policy elements incorporated in ESAP were: fiscal and monetary policy reforms, including budgetary and monetary stabilisation measures, and the liberalisation and deregulation of banking and finance. Trade liberalisation included the abolition of quantitative controls and the reduction and harmonisation of tariffs and duties. Deregulation of prices, wages, interest rates and exchange rates; public sector restructuring entailing the downsizing of the civil services, and the reorganisation and commercialisation of parastatals; a social-safety net in the form of Social Development Fund (SDF) for those vulnerable to the adverse effects of structural adjustment. ${ }^{50,51}$ Economic Structural Adjustment Programmes' specific targets included achieving an annual gross domestic product (GDP) growth rate of 5\% during the period 1991-1995; raising savings to $25 \%$ of GDP; raising investment to 25\% of GDP; achieving export growth rate of 9\% per annum during the period 1991-1998; reducing budget deficit from 10\% of GDP 5\% by 1995 and reducing inflation from over $17 \%$ to $10 \%$ by $1995 .{ }^{36}$

Economic Structural Adjustment Programmes affected the flow of aid to Zimbabwe negatively, and as Zhou and Zvoushe ${ }^{36}$ described it as the 'proverbial medicine that kills the patient'. As a result, the social indicators which were impressive in the 1980 s plummeted to very low levels. ${ }^{52}$ The economy stagnated to an average growth of $1 \%$ in real terms during the ESAP period (1991-1995) compared to 4\% during the pre-ESAP period (1985-1990). ${ }^{48}$ The situation was exacerbated by the change in ZANU PF's ideology from nominal socialism in 1992 to Structural Adjustment's version of liberal capitalism. ${ }^{6}$ The decision to espouse structural adjustment in 1992 was interpreted as an open door for the entry of neo-liberal capitalism. Structural adjustment did not give a boost to new industrialisation. Instead, it led to rapid de-industrialisation, as locally manufactured products were replaced by cheaper imports from East Asia. ${ }^{6}$

Higher levels of consumerism than ever before were achieved by the small black elite, whilst tens of thousands of black workers lost their jobs in the old industries. Employment which had grown at a rate of $2.4 \%$ decelerated to an annual average of $0.8 \%{ }^{18}$ At the same time, fees were introduced for hospital and clinic services which resulted in increased numbers of children out of school, people dying of curable diseases in their homes and women giving birth at home or in scotch carts on their way to health centres. ${ }^{48}$ Furthermore, this period witnessed a deterioration in health indicators as hospitals were severely affected by equipment and drug shortages. ${ }^{47,53}$ The health sector was also affected by a great exodus of qualified staff, nutritional deficiencies and congestion at casualty and mortuaries which was in stark contrast to the health gains made in the 1980s., ${ }^{3,48}$ The HIV and AIDS pandemic worsened the crisis, HIV prevalence rates reached close to $30 \%$, hospitals were overwhelmed and many people died, with some scholars estimating the death at 3000 every week. ${ }^{48}$

More so, Structural Adjustment ushered in a period of increased corruption by the political class, which saw the opportunity to secure a larger share of the economy through the political support they were able to give to private sector ventures from outside. ${ }^{6}$ The government's failure to control public spending and corruption was held responsible for the missing of economic reform targets under ESAP. Consequently, the disbursement of funds under the Enhanced Structural Adjustment Facility was suspended in September 1995 and funding was eventually withdrawn in $1999^{18}$ : the inflow of aid to Zimbabwe drastically fell (see Figure 1). The ESAP's Social Dimensions of Adjustment (SDA) component that was meant to cushion the impact of structural changes on vulnerable groups in society, amongst them retrenched workers, failed to reduce poverty as many of those who were retrenched did not get assistance to start income-generating projects. ${ }^{18}$ The international aid organisations were unable to adequately protect the poor from the adverse effects of economic decline $e^{47}$ despite the fact that they were the ones who prescribed the structural adjustments.

The adverse effects of ESAP caused tension between the state and the umbrella labour body, the Zimbabwe Congress of Trade Union (ZCTU). ${ }^{18}$ Clashes and running battles between workers and state police occurred with frequent regularity, much to the chagrin of the state. ${ }^{54}$ University students joined the fray as living conditions plummeted. It was against this background, the labour body, in consultation with civil society launched a new political party in August 1999 Movement for Democratic Change (MDC) led by the then ZCTU's Secretary General, Morgan Tsvangirai. ${ }^{18,41,54}$ With the support from labour and a multitude of civic organisations, the MDC provided the first real challenge to the ZANU PF party. ${ }^{9}$ It organised successful mass stay-aways which at times turned into violent demonstrations and the charged political environment eventually led donors to withhold aid and impose targeted sanctions on top government officials and other institutions. ${ }^{39}$ The issue of targeted sanctions is further elucidated in the subsequent section.

\section{Zimbabwe's programme of economic and social transformation}

The Zimbabwe Programme of Economic and Social Transformation (ZIMPREST) was belatedly introduced in $1998^{18}$ with the major aim of correcting the wrongs of the donor-funded ESAP. It was mainly hinged on the social development and welfare of the people. Zimbabwe Programme of Economic and Social Transformation envisaged a comprehensive restructuring of government which could achieve an efficient system of service delivery of basic facilities, economic empowerment, private sector development and job creation. ${ }^{18}$ The policy pillars of the ZIMPREST were 
constructed to directly tackle poverty which emanated as a result of the introduction of ESAP. Several strategies were put in place, amongst them land reform, indigenisation, small scale enterprises and national AIDS strategy. Unfortunately, ZIMPREST failed to address the effects of structural reforms and arresting the free fall of the Zimbabwean economy: in fact, it failed to meet its targets and the economy further deteriorated and poverty increased..$^{18}$ During the same year of 1997, the Zimbabwean dollar tumbled to its lowest level against the US dollar in the entire history of the country; in absolute figures, the Zimbabwean dollar depreciated in its exchange rate from 12 Zimbabwean Dollars per US dollar in October 1997 to 38 Zimbabwe dollars per US dollar. ${ }^{51}$ The government went on a panic mode and their strategy response was to tighten the monetary and fiscal policy as well as wholesome introduction of tariffs on imports and regulation of foreign exchange trading. ${ }^{50,51}$ During this period, aid inflow further deteriorated because of lack of trust between the donor community and the government ${ }^{18}$ as shown in Figure 1.

Although there were several strategies put in place to address the adverse effects of ESAP, the outstanding issue that needed immediate solutions was land. Therefore, in September 1998, a large donor conference was convened at the Sheraton Hotel in Harare, facilitated by the UNDP to solicit for aid for the land reform and resettlement programme. ${ }^{9,36,41}$ The conference aimed to raise $\$ 40 \mathrm{~b}$ Zimbabwean dollars (US $\$ 2.2 b$ ) in order to resettle 150000 families over 5 years. The meeting ended with agreement on principles for effective land reform and an agreement to begin with a 2-year donor-funded inception phase. Unfortunately, donors were not prepared to fund the inception phase and the only tangible result that emerged from the donor conference was a World Bank assisted project $(\$ 5 \mathrm{~m})$ aimed at testing the feasibility of two models for land reform that were designed to be an integral part of the inception phase. By the end of the conference about \$19m had been pledged by China and some local companies. The majority of foreign donors withheld their pledges pending the results of the pilot study. In addition, the donors also agreed that an inception phase to land reform should develop models like land policy and accompanying mechanisms for transparency and accountability. However, the government objected and the programme was never implemented. ${ }^{36}$ The other reason why the donor support of land reform plan of 1998 failed was that some businesses and farming communities openly funded a new political party to oppose land reform. ${ }^{9}$ This issue of a new political party and how it affected donor funding is critically discussed in the following section.

\section{The multi-party democracy period in Zimbabwe 2001-2008}

This period 2001-2008 was deliberately titled multi-party democracy period because this study argues that it marked the first ever seriously-existing opposition after the unity accord of 1987. Upon attainment of independence in 1980, Zimbabwe held elections under the new constitution, which was crafted at the Lancaster House conference. Amongst the tenets of the new constitution was democratic participation in elections by multi-party, hence the participation by ZANU
PF, PF, UANC and Ian Smiths' Rhodesian Front in the subsequent elections of $19800^{55}$ The issue of democratic participation by many political parties seemed to exist only on paper: in practice, it was a different issue altogether as the then president of ZANU wanted the state to be a one-party state. ${ }^{54}$ The ruling party then worked tirelessly to achieve their objective of creating a one-party state, and in the process they forced other parties to join them or face extinction. Joshua Nkomo's PF was the first casualty: in 1987 it joined ZANU and they formed ZANU PF. From this period up to 1999, Zimbabwe was technically a one-party state because the opposition that existed were just paper tigers. ${ }^{41,54}$ In other words, the country operated under a defacto one-party rule. The birth of MDC in 1999 ushered in more competitive party politics and for the first time since independence in 1980, the then ruling party ZANU PF's political feathers were ruffled and they felt threatened. ${ }^{36}$

The GoZ, which predominantly constituted members of ZANU PF proposed a constitutional reform and set 12 February 2000 as the date for voting. Amendment 17 to the Constitution of Zimbabwe was agreed upon by the parliamentarians in majority with the view of nationalising all white-owned commercial farmland. The then newly formed MDC vigorously campaigned against the constitutional reforms, and it is alleged that some of the white farmers were sponsoring the campaigns, which angered ZANU PF when people voted against the Constitutional Referendum that they were promoting. This prompted ZANU PF to adopt the most brutal methods of land redistribution and election campaigns, never before witnessed in the history of post-colonial Zimbabwe and probably Africa at large. ${ }^{56}$ All those who were perceived to have supported or voted for the 'No' vote became prime targets of violence. Following the people's 'No' vote against the constitution, the war veterans with the support of the government engaged in farm invasions. Land became a rallying point, as war veterans, war collaborators and supporters of the ruling party sporadically invaded white people owned farms in retaliation for their support to the MDC on the 'No' vote. ${ }^{40}$

After a majority of the people had voted ' $\mathrm{No}^{\prime}$ in the constitutional referendum in 2000, the nation was once again engaged in general elections later the same year. The general elections of 2000 were held under a cloud of violence. ${ }^{40}$ The irony of it was that the MDC won 57 seats. The EU, the USA, Britain and the Nordic states declared the elections were not free and fair. These events were to and have shaped the flow of aid to Zimbabwe in many ways as it is explained in the subsequent sub-sections. The flow of aid in Zimbabwe during the period 2001-2008 was characterised by mistrust and frustrations perpetrated by both the GoZ and the donor community. This period saw the flow of aid dwindling to its lowest level as compared to other periods before 2001-2008 and after (see Figure 1). Official Development Assistance (ODA) to Zimbabwe in million US dollars, at 2012 prices and exchange rates shows that the period 2000-2009 received the least amount (396m) as compared to other periods for 
example, 1980-1989 received (544m) and 2010-2013 received $(818 \mathrm{~m}) .{ }^{42}$ The decline could be attributed to a lot of changes which were taking place in both the economic and political arenas of the Zimbabwean country. Major milestones were the formation of MDC in 1999 and its participation in the referendum of $2000 .{ }^{9,41}$ Other historic events were the land invasions in 2000; parliamentary elections of 2000; targeted sanctions in 2001; presidential elections in 2002; the fall of the Zimbabwe dollar; illegal diamond panning which commenced in 2006; Murambatsvina 2005; the high HIV and AIDS prevalence and mass migration of people to other countries. ${ }^{36,40,56,57}$

\section{Targeted sanctions for Zimbabwe}

The years 2001-2008 were gloomy years for Zimbabwe in terms of development in general. In fact, the country suffered isolation from participating in global politics and economics because ZANU PF, the ruling party was accused of property and human rights violations. ${ }^{15,39}$ The lengthy isolation from the international community restricted the quantum of aid and resulted in a build-up of arrears to the majority of its multilateral and bilateral partners. ${ }^{58}$ In addition, a multiplicity of sanctions and punitive measures were imposed on Zimbabwe, amongst them were the Zimbabwe Democracy and Economic Recovery Act (ZIDERA) of 2001 enacted by the United States Congress; the suspension of the budgetary support previously provided to the government by the EU; the imposition of visa bans and asset freezes by the US, EU, Canada, Australia, and New Zealand on influential individuals associated with government and the ruling ZANU PF and the prohibition of military support and technical assistance which was perceived to be enhancing the government's repressive capacity. ${ }^{24}$ Of significance to flow of aid in Zimbabwe is the fact that ZIDERA empowered the US to veto Zimbabwe's application to multilateral agencies for finances, credit facilities, loan rescheduling and international debt cancellation. The humanitarian agencies' funding shortfall at the end of 2003 was US\$110m, 57\% of the amount sought, mainly due to lack of cooperation between the government and the international community which had a negative bearing on resource mobilisation..$^{59}$ The impact of the foreign aid freeze coupled with declining exports caused a drastic foreign currency shortage that in turn had a negative impact on imports. ${ }^{59}$ This could be the reason why Zimbabwe got the least aid in years, as shown in Figure 1. In terms of net order receipts, the period 2000-2009 registered the least ODA (US\$400m) as compared to 19801989 (US\$557m), 1990-1999 (US\$639m) and 2010-2014 (US\$810m). ${ }^{42}$

\section{Policy disagreements between the Zimbabwean government and the western donors}

The events of the years between 2001 and 2008 led to aid 'mood-swings' where Zimbabwe from a yester-years' darling of the donors became an enemy, resulting in a dramatic drop in donor-support. ${ }^{44}$ The mood-swings happened because of real and substantive policy differences between the GoZ and the international community. Often cited was the GoZ's widely publicised failure to curb rural violence related to the seizures of white-owned farms by blacks, and to hold free and fair elections. ${ }^{44}$ In 2001 war veterans threatened violence and land-grab from white owners, resulting in an immediate freeze on all development aid co-operation with the Zimbabwean government by other Organisation for Economic Co-operation and Development (OECD) countries such as Denmark. ${ }^{60}$ International community and donors were angered by what they perceived to be human and property rights violations; amongst them land seizure, beating and forcing people to support certain political parties. Hence some countries such as the USA and her allies vowed that they would not give aid to Zimbabwe until the government started observing the rule of law and human rights. ${ }^{59}$ The ruling party ZANU PF accused the donor community of meddling in the country's political affairs and funding the opposition with the agenda of effecting a regime change. ${ }^{11,61}$

Following the land invasions, Zimbabwe was suspended from the Commonwealth which was one of its major donors since pre-independence in $1965 .{ }^{62}$ The reasons for its suspension were mainly centred on human and property rights violations. The most cited one was the seizure of white owned land and ill-treatment of political opponents by the ruling party ZANU PF.59 Subsequently, the GoZ voluntarily withdrew from the Commonwealth in 2003 and consequentially aid stopped..$^{63}$ International Monetary Fund suspended technical assistance in June 2002 because of arrears aggregating more than US $\$ 132 \mathrm{~m}$ and in November 2003 began compulsory withdrawal procedures for Zimbabwe ${ }^{59}$ : policies that influenced the aid donors to withdraw aid.

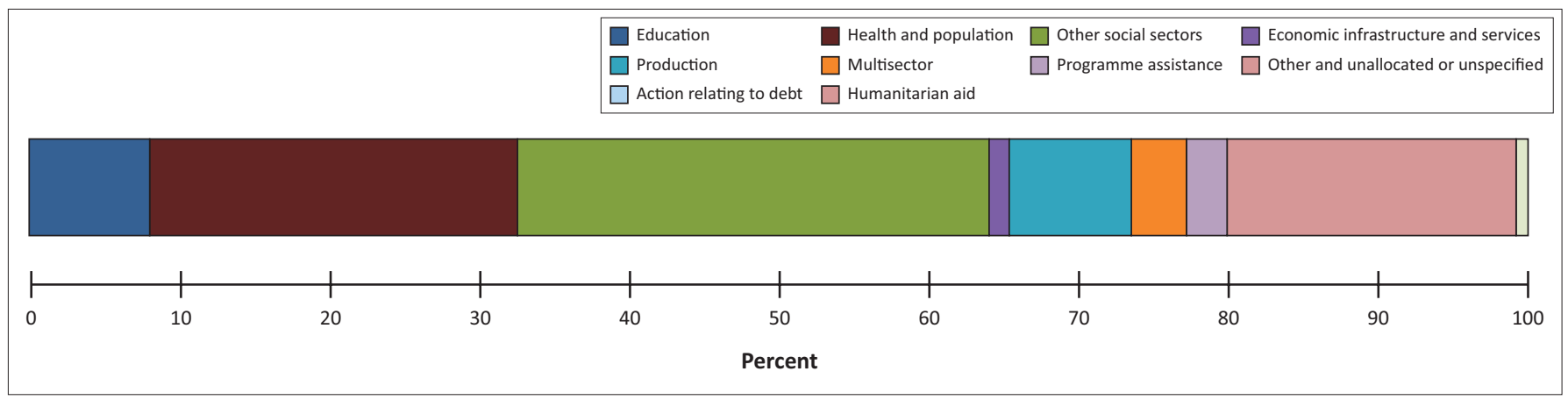

Source: Adapted from OECD - DAC, World Bank, https://www.oecd.org/dac/stats.

FIGURE 2: Resource flow to Zimbabwe 2010-2012. 
After the donors withdrew their aid the ZANU PF government introduced draconian policies to punish individuals and organisations they alleged to be imperialist agencies. To this end they introduced a number of bills and policies in order to punish what they perceived to be political enemies of ZANU PF such as: The Access to Information and Protection of Privacy Act (AIPPA) and Public Order and Security Act (POSA); and NGO Bill, The AIPPA. ${ }^{40,62}$ This brought an end to the democratic space and extinguished human freedoms as enshrined in the constitution. The NGO Bill, although it was never formulated into an Act, was very effective because it required all NGOs to register with the government in order to continue with their activities. This created a precarious condition for the NGOs to operate: if the government perceived any wrong doing, it would result in the withdrawal of the operating licence. ZANU PF sought to halt all donor activities in the country ${ }^{40,62}$ and the first victim was CARE International, an aid agency which was prohibited from distributing food aid in Masvingo Province. CARE was accused of using food to support the MDC. The ZANU PF government also issued another directive which placed all food distribution in rural areas under the command of Local Government Ministry. On 04 June 2004, the government suspended all local and international aid and banned the activities of humanitarian agencies entirely..$^{40}$ Against the backdrop of gross violation of law and human rights, external relations with the west deteriorated. ${ }^{41}$ Some donors like the UK ended direct support to the GoZ in 2002, whilst donor aid in general decreased, humanitarian aid increased, health sector aid in particular increased to $49 \%$ over the period $2002-2004 .^{3}$

\section{Impact of the political and socio-economic situation in Zimbabwe}

The deteriorating political and economic situation had a negative impact on the country. It led to economic meltdown which led to mass migration of people into the neighbouring countries, especially the Republic of South Africa. In fact, there was a massive flight of qualified manpower such as engineers, doctors, nurses and teachers. It is estimated that up to a third of the population crossed international borders during that period for various reasons, ranging from political violence to job seeking and perhaps, as well as Operation Murambatsvina, which destroyed people's homes. ${ }^{40}$ There was extensive deterioration of infrastructure and shortages of medicines in hospitals and clinics. ${ }^{40,59}$ The health sector was severely hit by the economic meltdown. In particular, many hospitals and other programmes were shut down in 2003 because of lack of funding. ${ }^{59}$ According to ${ }^{4}$ fragile states with poor resources to carry out basic governance functions have to rely on budget support from donors.

In a desperate attempt to retain some of the skilled workers, especially in the health sector, donors introduced the Health Worker Retention Scheme in 2007.64,65,66 The objective was to retain public health workers by supplementing their meagre salaries. ${ }^{67}$ The scheme was funded by EU and the Global Fund for AIDS, TB and Malaria, as well as other donors such as DFID, UNICEF, Australia and Denmark. ${ }^{67}$ The period 2001-2008 was also characterised by high prevalence of HIV and AIDS which resulted in many deaths. ${ }^{68}$ For example, in 2003 Zimbabwe had one of the highest rates of HIV infections in the world with an average antenatal HIV prevalence of 24.6\%. ${ }^{68}$ According to the 2005-2006 Zimbabwe Demographic and Health Survey (ZDHS), the HIV prevalence rate for adults aged $15-49$ was $18 \% .{ }^{69}$ Life expectancy dropped from 61 in 1990 to 43 years in 2003..$^{2}$

Corruption thrived, perpetrated by a few powerful individuals who were in the government or those directly connected to people who held powerful offices. ${ }^{54}$ Following a massive deterioration in the quality of policies and institutions, many donors were quick to come and help on humanitarian grounds, putting aside their frosty relations with the GoZ. ${ }^{67}$ Many donor funded programmes were introduced during this period, amongst them the Medecins Sans Frontieres Antiretroviral Therapy (MSF ART) Programme, Expanded Support Programme (ESP) for HIV and AIDS. ${ }^{67}$ The ESP for HIV and AIDS was introduced in 2007 and jointly funded by five bilateral donors: UK $(35 \mathrm{~m})$, Canada $(2.5 \mathrm{~m})$, Ireland $(5 \mathrm{~m})$, Norway $(2 \mathrm{~m})$ and Sweden $(7.5 \mathrm{~m})$ - all paid in pounds. ${ }^{67}$ The programme focused on HIV prevention through behaviour change promotion, treatment and care through procurement and distribution of antiretroviral drugs, and management and coordination of the provision of HIV and AIDS treatment. ${ }^{67}$

\section{The period of the Government of National Unity in Zimbabwe 2008-2013}

In September 2008, ZANU PF and the two MDCs signed a Global Political Agreement (GPA) which culminated in the formation of the GNU in March 2009. ${ }^{18}$ The GNU ushered in a new donor aid dispensation regime. In other words, Zimbabwe became a donor darling again as was the case in 1980s. ${ }^{6}$ Refreshed engagements started between the government and donors, such as African Development Bank (AfDB), EU, Canada, Denmark, Norway, Sweden, United Kingdom, United States, Australia, Germany, Netherlands, United Nations (UN) related agencies (UNDP, FAO, UNICEF, UNHCR, WFP, and the global Fund). ${ }^{10}$ Donors committed substantial amounts of aid, returning to a level last seen in the early 1990s but this time through 'off budget' grants which accounted for nearly $9 \%$ of the GDP. ${ }^{15,16}$ This could be attributed to the signing of the GPA in $2008^{15}$, which was sponsored and supported by the Southern African Development Community (SADC) to address the deleterious effect of political instability on the national economy. ${ }^{70}$

The same period manifested the first significant effort by the government to have meaningful institutional structures and systems to govern donor aid. The GNU put structures in place to ensure that aid was effectively and efficiently managed; amongst them the ACP, a fallout of the GDF in May 2009, was created as a platform for promoting dialogue between governments and donor partners. ${ }^{14}$ The ACP was established to provide a framework for enhanced aid effectiveness and accountability. The ACP was designed in a 
manner that would allow proper planning, aligning aid with national development plans prioritised in line with the Paris Declaration. ${ }^{20}$ The following are the policy objectives and policy targets as they were outlined in the Medium-Term Plan of Zimbabwe in 2011: to align aid with the national development programmes and priorities; re-orient aid from humanitarian to development assistance and increase the amount being channelled by development partners through the national budgets. ${ }^{20}$

The policy targets were as follows: to align humanitarian assistance to national priorities by 2012 ; align $50 \%$ of development aid to national priorities by 2015 and have $80 \%$ of aid channelled through the national budget by 2015 . However, these aid coordination systems were not fully effective because of a number of reasons: amongst them, fights for control by different political parties and line ministries during GNU and most importantly, the reluctance of some OECD governments to engage directly with the GoZ. ${ }^{15}$

The GNU also formed the Zimbabwe Accelerated Debt and Development Strategy (ZAADS), which was implemented through re-engagements with creditors, including the IMF, World Bank and the AfDB..$^{71,72}$ The notable milestone made by ZAADS is the re-engagement agreement between the government and the IMF in May 2013 for Staff Monitored Programme (SMP). ${ }^{72}$ The GNU also embarked on Zimbabwe Accelerated Re-engagement Programme (ZAREP) which was a product of consultations with key stakeholders such as government representatives, financial institutions, international organisations and others, and was meant to fasttrack engagement with donor and other development partners on policy issues. ${ }^{14}$ It was also envisaged as a gateway to new financing from the IFIs and the much-needed debt relief. In addition, the GNU also established the Zimbabwe Aid and Debt Management Office within the Ministry of Finance in December 2010 to manage debt. ${ }^{71}$ Zimbabwe received a lot of aid during the GNU mainly in the form of technical assistance and institutional capacity building which was funded with grant resources from Pillar 111 of the Fragile States Facilities (FSF). ${ }^{10}$ Absolute figures supplied by the AfDB indicate that the total allocation to Zimbabwe from FSF pillar III was UA $4005795 .^{73}$ According to AfDB, ${ }^{10}$ the assistance was largely aimed at improving economic governance and restoring vital public services.

\section{Disbursement of development aid by donors during the Government of National Unity in Zimbabwe}

According to OECD, aid flows remarkably improved during the GNU as shown in Table 2 and Table 3 as well as Figure 2. The tables show the OECD flows of ODA and other resources to Zimbabwe. For example, net ODA (USD million) fluctuated between 2010 and 2012, but remained very high. The gross national income per capita increased steadily for the same period (Table 2). The United States of America and the United Kingdom provided the bulk of the aid, each donated US $\$ 177 \mathrm{~m}$ and US $\$ 149 \mathrm{~m}$, respectively. Ironically, these were the two countries which were at the centre of the targeted sanctions against Zimbabwe. Their support could be

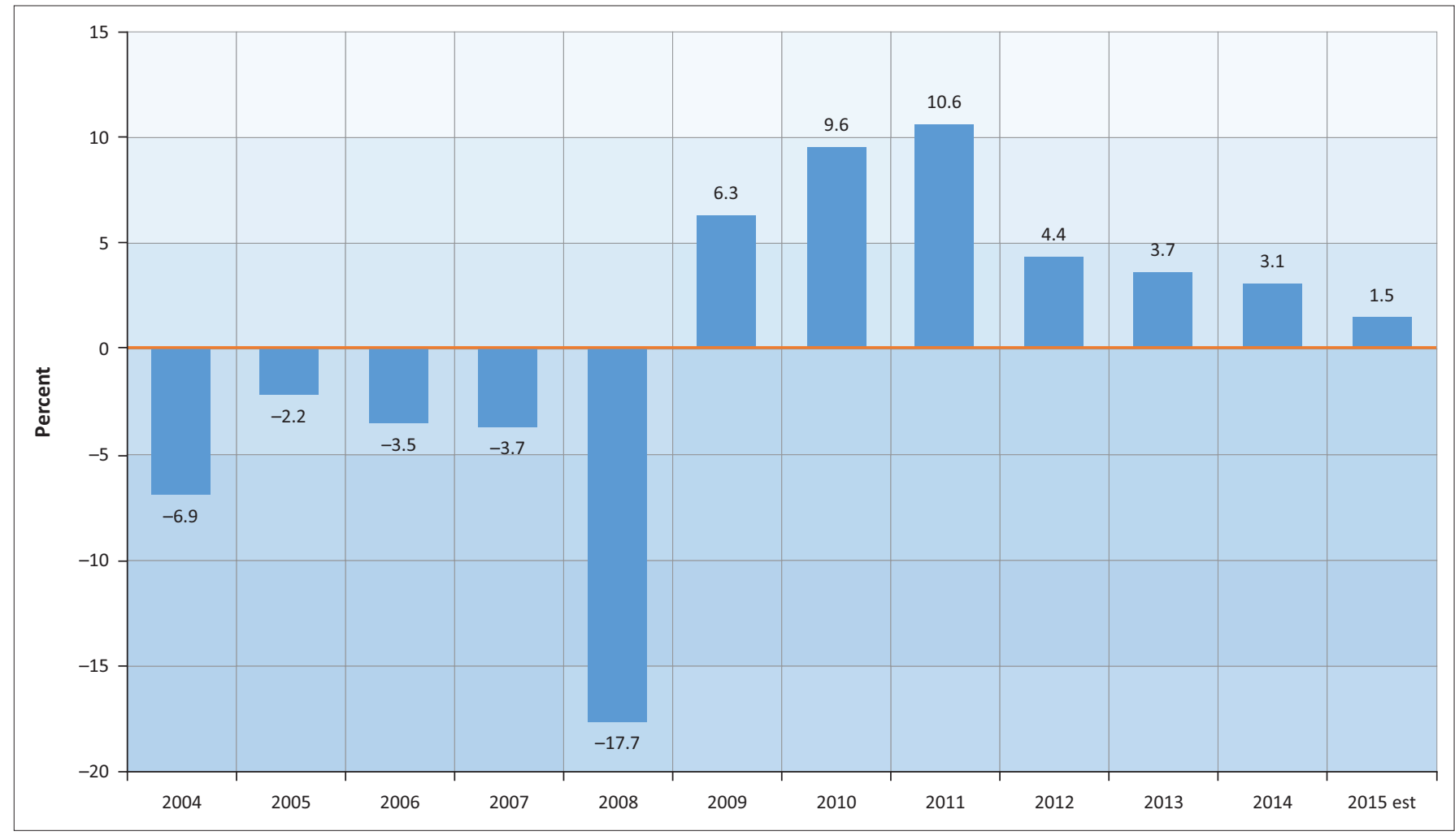

Source: Adapted from Zimbabwe National Statistics Agency (ZIMSTAT), ZimVAC, 2015.21

FIGURE 3: Zimbabwe Annual gross domestic product growth rates. 
as a result of the commitment which was shown by the Zimbabwean government to consolidate peace and security, which culminated in the signing of the GPA in 2008 and the creation of the inclusive government. ${ }^{10}$

As shown in the diagrammatic representation in Figure 2.2, Zimbabwe received aid in various forms. Since the formation of the GNU in 2009, there has been a recovery: economic growth reached $10.6 \%$ in 2011.21 Inflation stabilised, revenues and bank deposits recovered sharply. ${ }^{16}$ This growth cannot be wholly attributed to the flow of development aid but also to a resurgence of both public and donor spending, which played a part in the recovery of social services. ${ }^{58}$ International relations began to normalise, although some sanctions are still in place and the situation remains fragile ${ }^{67}$ Figure 3 shows the GDP growth rates of Zimbabwe from 2004 to 2015. It shows the marked difference between GDP growth rate which were all negative from 2004 to 2008, before the GNU's re-engagement with the international community and donors. From the year 2009 to 2013 the GDP growth rates were all positive, boosted by international aid which was estimated to be $30 \%$ of all government spending in 2011 and 8.6\% of GDP. ${ }^{16}$ But, as it has been noted above, the GDP growth cannot be wholly attributed to development aid; although it played a big role in the recovery of social services.

\section{Conclusion}

Zimbabwe got a lot of aid and was a donor darling from 1980 to 1990 because the donors wanted to rebuild a nation which was destroyed by war. The global politics which pitted the socialists and capitalists into an ideological war was another key to African countries' bid to lure aid. Not all aid is effective; the 1990s sponsored structural adjustments negatively impacted the socio-economic wellbeing of the country. The flow of aid is politically motivated as seen by the dwindling of aid during the period 20002008 when the Zimbabwean Government's relationship with the west was at its worst in its history. Lastly, the conclusion that aid is politically engrained during the GNU period when the Zimbabwean government frantically sought to re-engage with the west and aid started to flow abundantly to Harare.

\section{Acknowledgements}

None other than the two authors recorded as the main authors of the manuscript.

\section{Competing interests}

The authors declare that they have no financial or personal relationships that may have inappropriately influenced them in writing this research article.

\section{Authors' contributions}

B.M. and E.D. contributed equally to this research article.

\section{Ethical consideration}

This article followed all ethical standards for research without direct contact with human or animal subjects.

\section{Funding information}

The research received no specific grant from any funding agency in the public, commercial or not-for-profit sectors.

\section{Data availability statement}

Data sharing is not applicable to this article as no new data were created or analysed in this study.

\section{Disclaimer}

The views and opinions expressed in this article are those of the authors and do not necessarily reflect the official policy or position of any affiliated agency of the authors.

\section{References}

1. Ehrenfeld D. Foreign aid effectiveness, political rights and bilateral distribution J Humanit Assist [serial online]. 2004 [cited 2018 Sep 8]. Available from: http:// jha.ac/articles/a128.htm

2. Chigora P. On crossroads: Reflections on Zimbabwe's relations with Britain at the New Millennium. Turk J Int Relat. 2006;5(3):61-76.

3. Munyuki E, Jasi S. Capital flows in the health care sector in Zimbabwe: Trends and implications for the health systems. Harare: EQUINET; 2009.

4. OECD. Fragile States 2014: Domestic revenue mobilisation in fragile states [homepage on the Internet]. 2014 [cited 2014 June 11]. Available from: www. OECD.ORG/DAC/INCAF

5. Amusa K, Monkam N, Viegi N. The Nexus between foreign direct investment and foreign aid: An analysis of sub-Saharian African countries. Afr Finance J. 2016;18(2):45-68.

6. Chung F. Re-living the second Chimurenga: Memories from the liberation struggle in Zimbabwe. Stockholm: Stylus Publishing, LLC; 2006.

7. Murisa T. Social development in Zimbabwe. Discussion paper prepared for Development Foundation for Zimbabwe. Harare: Development Foundation for Zimbabwe: 2010.

8. Nyazema NZ. The Zimbabwe crisis and the provision of social services. J Develop Soc. 2010;26(2):233-261. https://doi.org/10.1177/0169796X1002600204

9. Bonarjee MFB. 3 decades of land reform in Zimbabwe. In perspectives socia justice and poverty alleviation. University of Bergen: Bergen Resource Centre for International Development, 2013; p. 1-35.

10. AfDB. Zimbabwe: Country brief 2011-2013. Abidjan: African Development Bank; 2011.

11. Gukurume S. Interrogating foreign aid and the sustainability development conundrum in African countries: A Zimbabwean experience of debt trap and service delivery. Int J Polit Good Governance. 2012;3(4):1-20.

12. Martinez J, Pearson M, Sorensen BH, James B, Sambo C. Evaluation of the health results innovation trust fund. Oslo: Norwegian Agency for Development Cooperation; 2012.

13. Monyau MM, Bandara A. Zimbabwe - African economic outlook [homepage on the Internet]. 2015. [cited 2015 Oct 14]. Available from: https://www.afdb.org/ fileadmin/uploads/afdb/Documents/Publications/AEO2015_EN.pdf

14. GoZ/UN. Zimbabwe 2012: Millennium development goals progress report 4. Harare: Government of Zimbabwe/UN; 2012.

15. Salama P, Ha W, Negin J, Muradzikwa S. Post-crisis Zimbabwe's innovative financing mechanisms in the social sectors: A practical approach to implementing the new deal for engagement in fragile states. BMC Int Health Hum Rights. 2014; 14(35):1-16. https://doi.org/10.1186/s12914-014-0035-6

16. Richardson CJ. Zimbabwe: Why is one of the world's least free economies growing so fast? Policy analysis no. 722. Washington: CATO; 2013.

17. EU. Development and cooperation [homepage on the Internet]. Paris: European Union-EuropeAid; 2013 [cited 2014 Oct 20]. Available from: http://ec.europa.eu/ europeaid/where/acp/countrycooperation/zimbabwe/zimbabwe_eu.htm

18. Mazingi L, Kamidza R. Inequality in Zimbabwe tearing us apart: Inequalities in Southern Africa. Johannesburg: Open Society Initiative for Southern Africa; 2010.

19. NAC. National AIDS Council- Coordinating the Multi- Sectoral Response to HIV and AIDS [homepage on the Internet]. 2017 [cited 2018 Mar 5]. Available from: nac. org.zw/funding

20. MoEPIP. Zimbabwe medium term plan, 2011-2015: Towards sustainable inclusive growth, human centred development, transformation and poverty reduction. Ministry of Economic Planning \& Investment Promotion; 2011. 
21. ZimVac. Zimbabwe vulnerability assessment committee market assessment report. Harare: Food and Nutrition Council; 2015.

22. Conyers D, Mellors R. Aid ineffectiveness in sub-Saharan Africa: The problem of donor capacity. IDS Bull. 2005;36(3):83-89. https://doi.org/10.1111/j.1759-5436. 2005.tb00225.x

23. Dowst M. Working with civil society in fragile states. Policy briefing paper 23 Oxford: International NGO Training and Research Centre; 2009.

24. Chikowore G. Contradictions in development aid: The case of Zimbabwe. Harare: Institute of Development Studies, University of Zimbabwe; 2010.

25. Muchadenyika D. Multi-donor trust funding and Fragile States: Assessing the aid effectiveness of the Zimbabwe multi-donor trust fund. J Int Develop. 2016; 28(8):1337-1357. https://doi.org/10.1002/jid.3237

26. Moyo L, Mafuso LT. The effectiveness of foreign aid on economic development in developing countries: A case of Zimbabwe (1980-2000). J Soc Sci. 2017:52(1-3): 173-187. https://doi.org/10.1080/09718923.2017.1305554

27. Giddens A. Sociology. London: Polity Press; 2016.

28. Amin S. Underdevelopment and dependency in black Africa: Historical origin J Peace Res. 1972;9(2):105-119. https://doi.org/10.1177/002234337200900201

29. Rodney W. How Europe underdeveloped Africa. New York, NY: McMillian; 1975.

30. Gunder-Frank A. Development and under development as concepts in economics. J Soc Sci. 1990;13(2):173-184.

31. Webster A. The society of development. New York, NY: Sage; 2015.

32. Schatzberg MG. The political economy of Zimbabwe. Praeger; 1984.

33. Foreign Affairs Committee. Zimbabwe: The role of British aid in the economic development of Zimbabwe (6). London: British Foreign Affairs Committee; 1981.

34. Auret D. A decade of development in Zimbabwe 1980-1990. Gweru: Mambo Press; 1990.

35. Mawowa S. Trapping into the chaos, crisis, state and accumulation in Zimbabwe. KwaZulu Natal: University of KwaZulu Natal; 2007.

36. Zhou G, Zvoushe H. Public policy making in Zimbabwe: A three decade perspective. Int J Humanit Soc Sci. 2012;2(8):212-222.

37. Takavarasha T. Zimbabwe's agricultural revolution. Harare: University of Zimbabwe Publishers; 1994.

38. Schwartz R. Coming to terms: Zimbabwe in the International Arena. London: I.B. Tauris; 2001.

39. Frame I, editor. Africa South of Sahara 2014. 43rd ed. New York, NY: Routledge; 2013.

40. Orner P, Holmes A. Don't listen to what I'm about to say: Voices of Zimbabwe. 1st ed. Johannesburg: Jonathan Ball Publishers; 2010.

41. Moyo S, Chambati, W. editors. Land and agrarian reforms in Zimbabwe: Beyond White-Settler Capitalism. Dakar: CODESRIA; 2013.

42. OECD. Development aid at a glance: Statistics by region. Development Assistance Committee; 2016.

43. MoEPD. Zimbabwe conference on reconstruction and development. Harare: Zimbabwe Government Printers; 1981.

44. Pomerantz PR. Aid effectiveness in Africa: Developing trust between donors and governments. Lanham: Lexington Books; 2004.

45. Mills G. Why Africa is poor: And what Africans can do about it? [homepage on the Internet]. 2011 [cited 2015 Oct 8]. Available from: http://penguinbooks.co.za/ book/why-africa-poor-and-what-africans-can-do-about-it/9780143528098

46. Bijlmakers LA, Bassett MT, Sanders DM. Health and structural adjustment in rura and urban Zimbabwe. Uppsala: Nordic Africa Institute; 1996.

47. Dhliwayo R. The impact of public expenditure management under ESAP on basic social services: Health and education. Harare: SAPRI; 2001.

48. Riddell RC. Does foreign aid really work? Oxford: Oxford University Press; 2007.
49. World Bank. World development report 1988. Washington, DC: International Bank for Reconstruction and Development/The World Bank; 1988.

50. Allen TW. Structural adjustment in Zimbabwe: The World Bank perspective. Harare: Conference Paper; 1999.

51. Chimanikire D. Accountable governance and poverty alleviation. Addis Ababa: Development Policy Management Forum Publications; 2000.

52. ZHDR. Zimbabwe Human Development Report: Redirecting our responses to HIV and AIDS. (Series 4). Harare: University of Zimbabwe; 2003.

53. Chevo T, Bhatasara S. HIV and AIDS programmes in Zimbabwe: Implications for the health system. Int Sch Res Notices. 2012:e609128. https://doi.org/10.5402/2012/ 609128

54. Towriss D. Buying loyalty: Zimbabwe's Marange Diamonds. J South Afr Stud. 2013;39(1):99-117. https://doi.org/10.1080/03057070.2013.765694

55. Newsnight Archives. Robert Mugabe's 1980 Victory: Newsnight special (1980). News night Archives. BBC: London; 1980.

56. Freeth B. Mugabe and the White African. Oxford: Lion Books; 2011.

57. OECD. Glossary of key terms in evaluation and results based management. Paris: Development Assistance Committee; 2004.

58. World Bank. Zimbabwe overview [homepage on the Internet]. 2015 [cited 2015 Aug 14]. Available from: http://www.worldbank.org/en/country/zimbabwe/overview

59. AfDB/OECD. African Economic outlook 2004/2005: Country studies [homepage on the Internet]. 2004 [cited 2015 Oct 8]. Available from: http://www.oecd.org/ dev/emea/africaneconomicoutlook20042005countrystudies.

60. AfDB/OECD. African Economic Outlook 2002: Zimbabwe. AfDB/OECD.

61. Jeater D. Zimbabwe: International NGOs and aid agencies - Parasites of the poor? [homepage on the Internet] 2011. [cited 2015 Aug 7]. Available from: africanarguments.org

62. De Bruin J. Zimbabwe's place in commonwealth. Accra: Commonwealth Human Rights Initiative; 2004.

63. CHRI. Zimbabwe's place in commonwealth. Accra. Commonwealth Human Rights Initiative; 2004

64. Chimbari MJ, Madhina D, Nyamangara F, Mtanwda H, Damba V. Retention incentives for health workers in Zimbabwe. EQUINET discussion pape no. 65 [document on the Internet]. 2008 [cited 2017 Aug 3]. Available from: http://www.equinetafrica.org/sites/default/files/uploads/documents/ Diss65ZimHRH.pdf

65. ICAI. The Department for International Development's support to the health sector in Zimbabwe (4). UK: The Independent Commission for Aid Impact; 2011.

66. Dieleman M, Watson M, Sisimayi C. Impact assessment of the Zimbabwe health worker retention scheme. Final report. London: DFID Human Development Centre; 2012.

67. ICAl. The Department for International Development's support to the health sector in Zimbabwe (4). London: DFID; 2011.

68. Perez F, Orne-Gliemann J, Mukotekwa T, et al. Prevention of mother to child transmission of HIV: Evaluation of a pilot programme in a District Hospital in Rural Zimbabwe. Br Med J. 2004;329:1147-1150. https://doi.org/10.1136/bmj.329. Zimbabwe.

69. Zimbabwe National Statistics Agency. Zimbabwe Demographic and Health Survey, 2010-2011. Harare: Zimbabwe National Statistics Agency; 2012.

70. Dzinesa GA. Zimbabwe's constitutional reform process: Challenges and prospects. Institute for Justice and Reconciliation; 2012.

71. AfDB/OECD/UNDP/UNECA. African economic outlook. African Development Bank; 2012.

72. AfDB/OECD/UNDP. African economic outlook 2014. Abidjan: African Development Bank; 2014

73. AfDB. Zimbabwe: Country brief 2011-2013. Abidjan: Africa Development Bank; 2013. 